\title{
Practical approval of the rating assessment of the budget potential of the territory
}

\author{
Galina Morunova ${ }^{1}$, Svetlana Gorbushina ${ }^{2}$, Olga Chesnova $^{3}$, and Svetlana Kuzmina, ${ }^{3, *}$ \\ ${ }^{1}$ St. Petersburg State Economic University, St. Petersburg, Russia \\ ${ }^{2}$ Saint-Petersburg State University, 13B Universitetskaya Emb., St Petersburg 199034, Russia \\ ${ }^{3}$ St.Petersburg State Institute of Film and Television, 13, Pravda str., St. Petersburg, Russia
}

\begin{abstract}
In the article the authors consider the issues of ensuring sustainable development of territories on the example of municipalities, methods of monitoring and evaluating the rating of a municipality, in particular, investigate the possibility of compiling a comprehensive rating for assessing the budget potential of a territory in order to analyze its impact on sustainable development. The authors also analyze the satisfaction of the population of municipalities with the activities of local authorities, including on the basis of an assessment of budgetary performance indicators. The authors suggest possible directions for applying the approved methodology for rating the sustainable development of municipalities to form a territory development strategy.
\end{abstract}

\section{Introduction}

Considering the municipality as an independent, complex dynamic economic system, corresponding to the general theory of systems, we will examine the questions of achieving sustainable development of local government, the organization of municipal finances in order to ensure the sustainability of the municipality. Sustainable development is a process of progressive changes in which the exploitation of natural resources, the direction of investment, the orientation of scientific and technological development, personal development and institutional changes are consistent with each other and strengthen the current and future potential to meet human needs. Development is a self-sustaining state, i.e. one that does not contradict the future existence of mankind and its development in the same direction. The sustainable development of a municipality means the ability of a municipal socioeconomic system to change from one non-equilibrium state to another, achieving a higher level and quality of population life, ensured by a sustainable, balanced and mutually non-destructive reproduction of the socio-economic and environmental potentials of the municipality (R. Sheveleva 2014 [1]).

\section{Research methodology and statistics}

\footnotetext{
*Corresponding author: kuzmina2003@bk.ru
} 
The organization of monitoring and evaluation of the development indicators of the territory and municipalities throughout the world has been going on for quite a long time and on an ongoing basis, which allows the formation of evaluative ratings of the activities of a territory or municipality. However, the lack of a comprehensive, final rating does not allow for an aggregate assessment of the situation in a particular municipality, which affects the final result of the rating (monitoring), distorting it as a whole.

It is proposed to conduct a study of the results of the organization of monitoring and ranking on the basis of a region such as the Leningrad Region (Russia). It should be noted that this is a fairly prosperous territorial and administrative entity, characterized by a balanced financial policy, which allows the region to occupy leading positions among the subjects of the North-West Federal District in terms of the main budget indicators - the level of budget deficit, the volume of public debt, as well as among the top twenty Russian regions on budget revenues. The Leningrad Region is a region where all the features of the organization of municipal finance are implemented. On its territory there are both municipal districts, and urban district, the settlement level is also well developed.

This justifies the reasonability of testing the rating of the sustainable development of municipalities on the example of this region, although, according to the authors, the developed methodology is universal and can be applied to any territory of the world national economy. This allows us to accurately estimate the level of sustainable development of municipal settlements located in the territory of the municipal district.

As foreign and the best domestic practice shows, the creation of conditions for the sustainable development of the territory at the municipal level makes it possible to successfully implement the goals of the state's economic policy as a whole. Issues of sustainable development of the territory and financial institutions that ensure this development are quite extensively considered in the domestic and foreign economic literature by such economists as Yilmaz Serdar (Subnational data requirements for fiscal decentralization: case studies from Central and Eastern Europe, 2003 [2]), Shah Anwar (Sustainability of territorial budgets, 2007 [3]), A-M. Berku., M. Tofan, E. Sigu (Issues of sustainable development at the local level, 2015 [4]), R. Zorzoliu (Regional sustainable development in Italy, 2012 [5]), I. Sharafutdinova, E. Shishkina (Emission activities of municipalities, 2016 [6]), V. Okrepilov (Monitoring issues assessing the sustainable development of the territory, 2015 [7]). The theory and methodology of sustainable development in Russia, including at the regional level, are currently explored by various authors, in particular, T.Uskova. 2008 [8]. At the same time, various monitoring, assessments, ratings are conducted at the municipal level, but all of them are not of a systemic nature, indicators vary, and factors that clearly influence the results obtained are not always reliably determined. The rating of sustainable development of cities in Russia is held annually [9], however, the assessment concerns only large cities, it is rather laborious in methodical terms, which for municipalities does not always allow it to be held on its own. Also in this rating there is no visible financial component, which, in our opinion, is one of the most important indicators for the municipality. If three components are considered to determine sustainable development at the regional level: economic, technological and environmental [10], then at the municipal level the situation is somewhat different. It remains obvious that many of the research questions of financial indicators that provide an assessment of the sustainable development of municipalities in the global and national economies remain unanswered. In our opinion, today municipalities may have a lesser degree of influence on the environmental component, since this area lies within the competence of the state and there are no statistical data in the context of municipalities. The financial and budgetary component (or, more correctly, the potential) should be included in the rating of the sustainable development of municipalities. In order to identify factors in 
the organization of municipal finances for the sustainable development of municipalities, it is logical to use already available information, such as:

- assessment of socio-economic development;

- assessment of the effectiveness of local government (public satisfaction with local government activities);

- budget execution data (budgetary sustainability).

So, according to the authors, the model of sustainable development of a municipality should be based on the following main components (potentials): socio-economic development, budgetary sustainability and effective local government activities (management potential), which results in population satisfaction with the activities of local government. The authors carried out a rating analysis of the sustainable development of municipal formations on the example of 17 municipal districts and one urban district of the Leningrad Region (Russia). At the first stage, indicators were selected by experts, which, in our opinion, characterize the state of the budget, the socio-economic development of the municipality, as well as the satisfaction of the population with the activities of local governments. The task in the formation of an integrated sustainable development rating of municipalities is also to evaluate the budget component (financial sustainability) to determine the municipalities that fall into the risk zone. When conducting research (the results of which are examined in more detail in the monograph by G. Morunova [11, 12]), the final rating of the municipalities of the Leningrad Region was compiled (Table 1).

Table 1. Rating of municipalities of the Leningrad Region (Russia) by potential for ustainable development [5].

\begin{tabular}{|c|c|c|c|c|c|c|c|}
\hline \multirow{2}{*}{$\stackrel{\circ}{Z}$} & & \multicolumn{3}{|c|}{$\begin{array}{l}\text { The amount of seats in the components } \\
\text { of the } 2014 \text { rating by: }\end{array}$} & \multicolumn{3}{|c|}{$\begin{array}{l}\text { The amount of seats in the components } \\
\text { of the } 2016 \text { rating by: }\end{array}$} \\
\hline & & $\begin{array}{c}\text { Socio-economic } \\
\text { potential }\end{array}$ & $\begin{array}{c}\text { Managerial } \\
\text { potential }\end{array}$ & $\begin{array}{c}\text { Budgetary } \\
\text { potential }\end{array}$ & $\begin{array}{c}\text { Socio-economic } \\
\text { potential }\end{array}$ & $\begin{array}{c}\text { Managerial } \\
\text { potential }\end{array}$ & $\begin{array}{c}\text { Budgetary } \\
\text { potential }\end{array}$ \\
\hline 1 & $\begin{array}{l}\text { Boksitogorsky } \\
\text { municipal district }\end{array}$ & 2 & 13 & 16 & 12 & 18 & 13 \\
\hline 2 & $\begin{array}{l}\text { Volosovsky } \\
\text { municipal district }\end{array}$ & 9 & 3 & 12 & 3 & 11 & 11 \\
\hline 3 & $\begin{array}{l}\text { Volkhovsky } \\
\text { municipal district }\end{array}$ & 8 & 17 & 10 & 8 & 15 & 5 \\
\hline 4 & $\begin{array}{l}\text { Vsevolozhsky } \\
\text { municipal district }\end{array}$ & 1 & 15 & 1 & 4 & 2 & 1 \\
\hline 5 & $\begin{array}{l}\text { Vyborgsky } \\
\text { municipal district }\end{array}$ & 17 & 16 & 3 & 11 & 8 & 3 \\
\hline 6 & $\begin{array}{l}\text { Gatchinsky } \\
\text { municipal district }\end{array}$ & 11 & 14 & 2 & 9 & 10 & 2 \\
\hline 7 & $\begin{array}{l}\text { Kingiseppsky } \\
\text { municipal district }\end{array}$ & 6 & 9 & 9 & 16 & 5 & 10 \\
\hline 8 & $\begin{array}{l}\text { Kirishsky } \\
\text { municipal district }\end{array}$ & 12 & 2 & 5 & 5 & 3 & 14 \\
\hline 9 & $\begin{array}{l}\text { Kirovsky } \\
\text { municipal district }\end{array}$ & 13 & 7 & 6 & 18 & 9 & 8 \\
\hline 10 & $\begin{array}{l}\text { Lodeinopolsky } \\
\text { municipal district }\end{array}$ & 7 & 6 & 14 & 2 & 7 & 18 \\
\hline 11 & $\begin{array}{l}\text { Lomonosovskiy } \\
\text { municipal district }\end{array}$ & 18 & 5 & 11 & 17 & 6 & 6 \\
\hline 12 & $\begin{array}{l}\text { Luzhsky } \\
\text { municipal district }\end{array}$ & 10 & 8 & 7 & 6 & 12 & 7 \\
\hline 13 & $\begin{array}{l}\text { Podporozhsky } \\
\text { municipal district }\end{array}$ & 3 & 12 & 17 & 1 & 4 & 16 \\
\hline 14 & $\begin{array}{l}\text { Priozersky } \\
\text { municipal district }\end{array}$ & 18 & 5 & 11 & 10 & 17 & 12 \\
\hline 15 & $\begin{array}{l}\text { Slantsevsky } \\
\text { municipal district }\end{array}$ & 8 & 17 & 10 & 7 & 13 & 15 \\
\hline 16 & $\begin{array}{l}\text { Sosnovoborsky } \\
\text { urban district }\end{array}$ & 17 & 16 & 3 & 15 & 1 & 17 \\
\hline 17 & $\begin{array}{l}\text { Tikhvinsky } \\
\text { municipal district }\end{array}$ & 16 & 11 & 13 & 14 & 14 & 9 \\
\hline
\end{tabular}




\begin{tabular}{|c|l|c|c|c|c|c|c|}
\hline 18 & $\begin{array}{l}\text { Tosnensky } \\
\text { municipal district }\end{array}$ & 14 & 18 & 18 & 13 & 16 & 4 \\
\hline
\end{tabular}

Now we are ranking the presented aggregate of municipal districts into separate clusters by indicators of 2016. We obtain the following data (Table 2):

Table 2. Ranking of municipalities for budget potential.

\begin{tabular}{|l|l|l|}
\hline \multicolumn{1}{|c|}{ 1 cluster } & \multicolumn{1}{|c|}{ 2 cluster } & \multicolumn{1}{c|}{ 3 cluster } \\
\hline $\begin{array}{l}\text { Vsevolozhsky municipal } \\
\text { district }\end{array}$ & Volosovsky municipal district & $\begin{array}{l}\text { Boksitogorsky municipal } \\
\text { district }\end{array}$ \\
\hline $\begin{array}{l}\text { Vyborgsky municipal } \\
\text { district }\end{array}$ & Volkhovsky municipal district & Kirishsky municipal district \\
\hline $\begin{array}{l}\text { Gatchinsky municipal } \\
\text { district }\end{array}$ & Kingiseppsky municipal district & $\begin{array}{l}\text { Lodeinopolsky municipal } \\
\text { district }\end{array}$ \\
\hline & Kirovsky municipal district & $\begin{array}{l}\text { Podporozhsky municipal } \\
\text { district }\end{array}$ \\
\hline & $\begin{array}{l}\text { Lomonosovskiy municipal } \\
\text { district }\end{array}$ & Slantsevsky municipal district \\
\hline & Luzhsky municipal district & Sosnovoborsky urban district \\
\hline & Priozersky municipal district & \\
\hline & Tikhvinsky municipal district & \\
\hline & Tosnensky municipal district & \\
\hline
\end{tabular}

The first cluster includes areas with the best budget component, the second cluster has an average budget component, and the third cluster has a low budget component. There were no major changes in the distribution of municipal districts into separate clusters, regarding the division made earlier by the 2014 indicators. The exception was Kirishsky municipal district. Being in 2014 in a cluster with an average level of implementation of the municipal budget, according to the indicators of 2016 this municipal district moved to a cluster with a low budget component.

Clusters were built on the basis of the first main component, which is largely influenced by indicators of revenues and expenditures of the budget. Looking more closely at the initial indicators and comparing them over the years, it can be noted that in 2016 the Kirishisky municipal district experienced a decrease in budget revenues and an increase in expenditures and subsidies to equalize fiscal capacity. The division into clusters of the second main component (the level of population satisfaction with the activities of local governments) will look as follows (Table 3):

Table 3. Ranking on clusters by the level of population satisfaction with the activities of local governments (managerial potential).

\begin{tabular}{|l|l|l|}
\hline \multicolumn{1}{|c|}{ 1 cluster } & \multicolumn{1}{c|}{ 2 cluster } & \multicolumn{1}{c|}{ 3 cluster } \\
\hline Volosovsky municipal district & Volkhovsky municipal district & $\begin{array}{l}\text { Boksitogorsky municipal } \\
\text { district }\end{array}$ \\
\hline $\begin{array}{l}\text { Vsevolozhsky municipal } \\
\text { district }\end{array}$ & Vyborgsky municipal district & Kingiseppsky municipal district \\
\hline $\begin{array}{l}\text { Lodeinopolsky municipal } \\
\text { district }\end{array}$ & Gatchinsky municipal district & Kirovsky municipal district \\
\hline $\begin{array}{l}\text { Podporozhsky municipal } \\
\text { district }\end{array}$ & Kirishsky municipal district & $\begin{array}{l}\text { Lomonosovskiy municipal } \\
\text { district }\end{array}$ \\
\hline & Luzhsky municipal district & Tikhvinsky municipal district \\
\hline & Priozersky municipal district & Tosnensky municipal district \\
\hline & Slantsevsky municipal district & Sosnovoborsky urban district \\
\hline
\end{tabular}


The first cluster here includes municipal districts with the highest level of population satisfaction with the activities of local governments, the second with medium levels, and the third with low levels of population satisfaction with the activities of local governments.

Next we divide the municipal districts into three groups according to the values of the third main component (socio-economic development of the municipal district) (Table 4).

Table 4. Ranking on clusters by the level of the socio-economic development of the municipality.

\begin{tabular}{|l|l|l|}
\hline \multicolumn{1}{|c|}{ 1 cluster } & \multicolumn{1}{|c|}{ 2 cluster } & \multicolumn{1}{c|}{ 3 cluster } \\
\hline $\begin{array}{l}\text { Vsevolozhsky municipal } \\
\text { district }\end{array}$ & Vyborgsky municipal district & $\begin{array}{l}\text { Boksitogorsky municipal } \\
\text { district }\end{array}$ \\
\hline $\begin{array}{l}\text { Kirishsky municipal } \\
\text { district }\end{array}$ & Gatchinsky municipal district & Volosovsky municipal district \\
\hline $\begin{array}{l}\text { Sosnovoborsky urban } \\
\text { district }\end{array}$ & Kingiseppsky municipal district & Volkhovsky municipal district \\
\hline & Kirovsky municipal district & Luzhsky municipal district \\
\hline & $\begin{array}{l}\text { Lodeinopolsky municipal } \\
\text { district }\end{array}$ & Priozersky municipal district \\
\hline & $\begin{array}{l}\text { Lomonosovskiy municipal } \\
\text { district }\end{array}$ & Slantsevsky municipal district \\
\hline & $\begin{array}{l}\text { Podporozhsky municipal } \\
\text { district }\end{array}$ & Tikhvinsky municipal district \\
\hline & & Tosnensky municipal district \\
\hline
\end{tabular}

The first cluster has the highest level of socio-economic development, the second has an average level of socio-economic development and the third has a low level of socioeconomic development. Unlike the rankings built on the first main component (budget), where the change in groups was insignificant, the rankings built on the second (satisfaction) and third (socio-economic) main components were distributed differently in different years.

\section{Discussion}

Considering the composition of the groups, it can be noted that there is no direct dependence of the population's satisfaction with the activities of local government on the budget implementation indicators [13]. Firstly, in our opinion, at the moment, the method of determining population satisfaction with the activities of local government requires further work. Secondly, the nominal accrued wages affect the satisfaction of the population. Indeed, the level of wages can influence people's opinions: the higher the income, the higher the demand and, accordingly, the satisfaction with certain services.

Next, consider the group of socio-economic development and public satisfaction with the activities of local governments. At first glance, there is no clear relationship. The distribution of municipal districts in 2014 and 2016 in each cluster was different. When considering the dynamics of changes, it is noticeable that in the areas in which the level of socio-economic development increased in 2016, the indicator of satisfaction with the activities of local authorities also increased, which suggests the existence of a definite obvious relationship between these criteria.

Previously the authors conducted a ranking of municipalities according to 2014 data. The rating of municipal districts turned out to be different from the rating compiled for 2016. Comparing we note a significant increase in ranking positions in the Podporozhsky, Vyborgsky and Gatchinsky municipal districts. Moreover, the changes in the budget potential have been insignificant. The growth of positions in the ranking was influenced by indicators of socio-economic potential and (to a greater extent) managerial potential. The same situation is when considering municipal districts, whose rating has fallen compared 
with 2014. For example, such as Tosnensky, Slantsevsky, Boksitogorsky municipal districts. The position of areas in the ranking here is also largely influenced by indicators of socio-economic and management potentials. The exceptionally budgetary component influenced the position in the rating of Sosnovoborsky urban district.

The results of the ratings confirm the crucial importance of socio-economic and managerial potentials, since the effectiveness of finances is determined by their dynamism, flexibility, ability to quickly and adequately respond to changes in external factors and internal socio-economic conditions of development. As the research shows, this is primarily manifested at the municipal level, where every decision is checked in everyday life and invariably affects the economic and social indicators of the state and development of the territory.

In this regard, the activation of such factors of sustainable development as the quality of human capital, the formation of a flexible financial infrastructure, the business climate, etc. is seen as a priority. These indicators can be regarded as promising ways to expand the financial base, the formation of the investment attractiveness of the territory and sustainable budgetary security. (for more information: S.Gorbushina [14]). In these transformations, there should be an active power built on the best practices and budget management theory, civil society, their new role in ensuring a strategic social and economic result for the territory aimed at sustainable development.

\section{Conclusions}

Thus, the study of issues of sustainable development of territories on the example of municipalities allows us to draw the following conclusions.

The indicators selected by experts characterizing the state of the budget, the socioeconomic development of the municipality, the population's satisfaction with the activities of local government adequately reflect the main aspects of the life of a particular territory, and because of this, they reasonably form the basis of the proposed methodology for forming a comprehensive sustainable development rating of municipalities. At the same time, the assessment of the budget component, which largely determines financial sustainability, is of particular importance, which makes it possible to identify municipalities that fall into the risk zone. An analysis of extensive statistical material on the example of a number of territories in Russia makes it possible to judge the relevance of information and recommend this methodology for wider use.

It should also be noted that the concept of sustainable development of any territorialadministrative entities implies the preservation of the unity of the economic, social and natural components as the basis for the harmonious development of territorial subsystems and the most important aspect of the activities of local administrations.

\section{References}

1. R. Sheveleva, Actual problems of economic sciences: materials of the III Intern. scientific conf., 160-162 (2014) https://moluch.ru/conf/econ/archive/95/5534/

2. Y. Serdar, Subnational data requirements for fiscal decentralization: case studies from Central and Eastern Europe (World bank, Washington, 2003)

3. S. Anwar, Local budgeting (World bank, Washington, 2007) 
4. A-M. Berku, M. Tofan, E. Sigu, Theory of Economics and Finance 20, 65-71 (2015)

5. R. Zorzoliu, Methodology - Social and Behavioral Sciences 58, 514-522 (2012)

6. I. Sharafutdinova, E. Shishkina, Globalization And Its Socio-Economic Consequences, 16th International Scientific Conference, Proceedings Part IV - Zilina, Slovakia, 19891995 (2016)

7. V. Okrepilov, Economics of quality for sustainable development (Publishing House of Peter the Great St. Petersburg Polytechnical University, St.Petersburg, 2015)

8. T. Uskova, Management of sustainable development of the region: a monograph (Vologda, 2009)

9. V. Artyukhov, S. Zabelin, E. Lebedeva, A. Martynov, M. Mirutenko, I. Ryzhov, Ratings of Sustainable Development of the Regions of the Russian Federation (Interfax, 2011)

10. P. Bychkov, E. Dolgikh, V. Erlich, P. Kuznetsova, Demoscope Weekly, 677-678 (2016) http://demoscope.ru/weekly/2016/0677/demoscope677.pdf

11. G. Morunova, Theory, legislation and practice of organizing municipal finance in a transformational economy (St. Petersburg, 2016)

12. G. Morunova, S. Kuzmina, T. Sorvina, MATEC Web of Conferences 193, 05058 (2018) https://www.matec-conferences.org/articles/matecconf/pdf/2018/52/matecconf_ esci2018_05058.pdf

13. A. Evmenov, S. Kuzmina, V. Vlasova, MATEC Web of Conferences 170, 01033 (2018)

14. S. Gorbushina, Public Finance: Past and Present: monograph (Tyumen, 2013) 